\title{
ЭПИДЕМИОЛОГИЧЕСКАЯ ХАРАКТЕРИСТИКА
}

\section{И ИММУНОЛОГИЧЕСКИЕ АСПЕКТЫ ИНФЕКЦИОННОЙ ПЕРИНАТАЛЬНОЙ ПАТОЛОГИИ}

\author{
Т.И. Долгих, М.В. Шелев, Ю.И. Тирская, Т.Н. Белкова \\ Омская государственная медицинская академия, г. Омск
}

Резюме. С целью оптимизации диагностики внутриутробных инфекций проведен анализ основных показателей по родовспоможению в Омской области за период 2000-2010 гг. Установлено снижение показателей перинатальной смертности в 2,5 раза (с 14,3 до 5,7 на 1000 родившихся) и ранней неонатальной смертности (с 6,5 до 0,9 на 1000 родившихся). При обследовании 187 новорожденных (85 пар «мать-ребенок») моноинфекция была в 24\% случаев, микст-инфекции - в $7 \%$ случаев с преобладанием герпесвирусов (HHV-6, CMV, EBV, HSV1,2). У детей с реализованной инфекцией имели место повышенное содержание цитотоксических T-лимфоцитов, усиленная экспрессия антигена HLA-DR на моноцитах и усиленная продукция хемокина IL-8.

Ключевые слова: эпидемиология, новорожденные, внутриутробные инфекции, лимфоциты, цитокины.

\section{EPIDEMIOLOGIC CHARACTERISTICS AND IMMUNOLOGICAL ASPECTS OF PRENATAL INFECTION Dolgih T.I., Shelev M.V., Tirskaya J.I., Belkova T.N.}

Abstract. To improve diagnostics of prenatal infections the basic obstetrics indices in Omsk region in the period of 2000-2010 years have been analyzed. It was found that perinatal mortality reduced 2.5 times (from 14.5 till 5.7 per 1000 newborns) as well as neonatal mortality (from 6.5 till 0.9 per 1000 newborns). The laboratory testing of 187 newborns ( 85 pairs mother-newborn) revealed monoinfection in $24 \%$ of cases and mixed infection in $7 \%$ of cases with predomination of herpes viruses (HHV-6, CMV, EBV, HSV1,2). Newborns with manifested infections had increased number of cytotoxic T-cells, intensive expression of HLA-DR antigens on monocytes and IL-8 chemokine increased production. (Infekc. immun., 2012, vol. 2, N3, p. 651-656)

Key words: epidemiology, newborns, prenatal infection, lymphocytes, cytokines.

\section{Введение}

Перинатальные инфекции представляют собой важную медико-социальную проблему вследствие неблагоприятного их воздействия на здоровье беременной женщины, плода и ребенка, приводя в ряде случаев к перинатальным потерям и влияя на показатели младенческой заболеваемости и смертности $[1,2,3$, $5,7,8,14,15,23]$. Среди возбудителей данной группы инфекций важная роль в формиро- вании патологии отводится герпесвирусам (Cytomegalovirus - CMV; Herpes simplex virus HSV1,2; Epstein-Barr virus - EBV) [4, 7, 11, 13, 19, 22], Toxoplasma gondii (T. gondii) [5, 6, 20]. В последние годы обсуждается патогенетическая значимость и парвовируса В19 [7, 21]. Снижению риска инфекционно-воспалительных заболеваний в системе «мать-новорожденный» придается особое значение [7, 21]. В настоящее время продолжается поиск путей решения данной проблемы, который включает как поступила в редакцию 01.07.2011 отправлена на доработку 11.07.2011 принята к печати 21.10.2011

(с) Долгих Т.И. и соавт., 2012

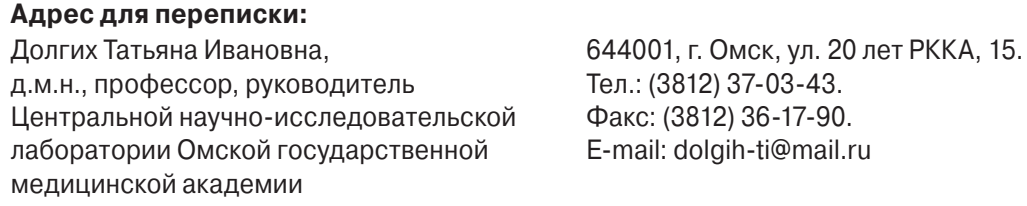

Долгих Татьяна Ивановна, д.м.н., профессор, руководитель Центральной научно-исследовательской лаборатории Омской государственной медицинской академии

644001, г. Омск, ул. 20 лет РККА, 15. Тел.: (3812) 37-03-43. Факс: (3812) 36-17-90 E-mail: dolgih-ti@mail.ru 
изучение структуры инфекций перинатального периода на конкретной территории, так и выделение иммунологических маркеров развития инфекции в организме $[7,12,14,16]$. Важное значение в диагностике и прогнозировании риска имеет оценка цитокиновой регуляции [9, 10, 18].

Целью исследования явилась оптимизация диагностики внутриутробных инфекций на основе этиологической расшифровки и оценки иммунореактивности у новорожденных детей различного срока гестации.

\section{Материалы и методы}

Исследования проведены в два этапа: І этап — изучение эпидемиологических аспектов перинатально значимых инфекций на основе этиологической расшифровки; II этап - оценка состояния иммунной системы и цитокиновой регуляции у новорожденных.

При эпидемиологическом исследовании проведен анализ основных показателей по родовспоможению в сравнении с общероссийскими данными (статистические формы № 13, 32), и здравоохранения г. Омска («Сведения о медицинской помощи беременным, роженицам и родильницам», форма № 32), ретроспективный анализ заболеваемости доношенных и недоношенных новорожденных в г. Омске за период с 2000 по 2010 гг.

Оперативный анализ включал обследование 187 новорожденных с подозрением на внутриутробную инфекцию (ВУИ), поступивших для оказания специализированной помощи в педиатрический стационар. В 85 случаях дети были обследованы параллельно с матерью. Материалом для исследования служили: венозная кровь, урогенитальные соскобы, соскобы из зева, моча и ликвор (по показаниям). Дети с верифицированной инфекцией составили 1 группу. В группу сравнения (2 группа) вошли 25 новорожденных с церебральной ишемией 1-2 степени и с отрицательными результатами обследования на внутриутробные инфекции, не получавшие специфической терапии.

Этиологическая расшифровка базировалась на результатах следующих методов:

- полимеразной цепной реакции (ПЦР), направленной на выявление ДНК потенциальных возбудителей (Chlamydia trachomatis, Ureaplasma urealyticum, Mycoplasma hominis, Mycoplasma genitalium, CMV, HSV-1,2, EBV, Human herpes virus 6 типа - HHV-6, Parvovirus B19, Listeria monocytogenes, T. gondii, Rotavirus, Enterovirus) с использованием коммерческих наборов (производство ФГУН «Центральный научно-исследовательский институт эпидемиологии», Москва, Россия);

- микробиологических исследований с использованием тест-систем «Genital system ${ }^{\circledR}$ » и «Vagicult ${ }^{\circledR}$ » (производство компании «Liophilchem», Италия) с дополнительным высевом на кровяной агар;

- иммунофлюоресценции для выявления антигенов возбудителей («ранние белки») HSV-1,2, CMV, T. gondii (наборы компании «VIRCELL microbiologists» (Испания);

- иммуноферментного анализа (ИФА), позволяющего выявлять специфические $\mathrm{IgA}$, $\operatorname{IgM}, \operatorname{IgG}$ и индекс авидности IgG к CMV и $T$. gondii на наборах производства компаний ЗАО «ВЕКТОР-БЕСТ» (Новосибирская область, Россия), «EUROIMMUN» (Германия), ООО НПО «Диагностические системы» (Нижний Новгород, Россия).

На II этапе работе изучали субпопуляционный состав лимфоцитов периферической крови $\left(\mathrm{CD}^{+} / 19^{-}, \mathrm{CD}^{+} / 4^{+}, \mathrm{CD}^{+} / 8^{+}, \mathrm{CD}^{-} / 19^{+}, \mathrm{CD}^{-} /\right.$ $16^{+} / 56^{+}, \mathrm{CD}^{+} / 25^{+}, \mathrm{CD}^{+} / \mathrm{HLA}-\mathrm{DR}^{+}, \mathrm{CD}^{+} / 95^{+}$, $\mathrm{CD}^{+} / 50^{+}, \mathrm{CD}^{+} 4^{+} / \mathrm{HLA}_{-} \mathrm{DR}^{+}, \mathrm{CD}^{+} / 19^{+}$) на проточном цитофлюориметре «Cytomics FC 500» с автоматической пробоподготовкой образцов на станции «TQ-Prep» компании «BeckmanCoulter» (США). Уровень цитокинов (IL-1 $\beta$, IL-2, IL-4, IL-6, IL-8, IL-10, RAIL-1 $\beta$, TNF $\alpha$ ) определяли на коммерческих тест-системах для ИФА-диагностики, произведенных в ЗАО «ВЕКТОР-БЕСТ» (Новосибирская область, Россия) и ООО «Протеиновый контур» (СанктПетербург, Россия), а мультиплексное определение цитокинов - на проточном лазерном иммуноанализаторе с использованием коммерческих наборов «Human Cytokine 27-plex» (BioRad, США).

Для обработки полученных в ходе исследования результатов была использована авторская программа «Статистический анализ

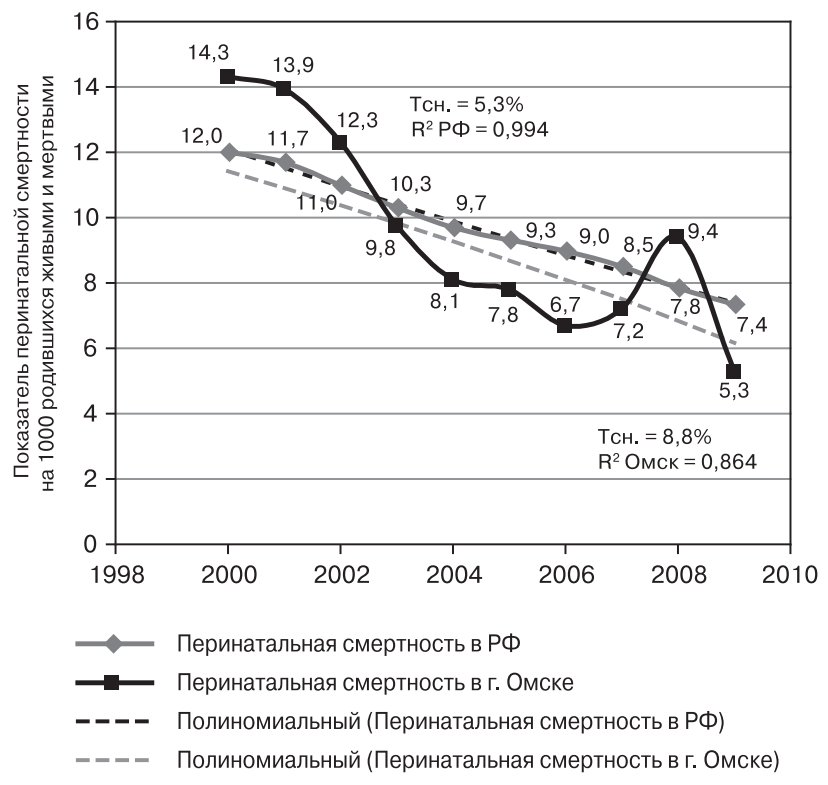

Рисунок 1. Динамика перинатальной смертности (на 1000 родившихся живыми и мертвыми) в г. Омске и в РФ за 2000-2009 гг. 
клинико-лабораторных данных для прогнозирования риска развития патологии R_MED» (Свидетельство о государственной регистрации программы для ЭВМ № 2011614225). В построении графических изображений использовался офисный пакет Microsoft Excel 2007. В зависимости от типов данных и решаемых задач применялись параметрические и непараметрические методы статистики. В анализе использовались методы описательной статистики (медиана Ме, 25 и 75 квартили). Уровень значимости различий величин сравниваемых групп при условии нормального распределения определяли с использованием двухвыборочного t-теста для групп с разными дисперсиями, при ненормальности распределения использовался критерий Манна-Уитни. Для анализа номинальных данных применяли критерий Фишера и $\chi^{2}$ Пирсона, для определения достоверности различия долей при частотном анализе модифицированный метод Макнамара. Статистически значимыми считали различия при $\mathrm{p}<0,05$.

\section{Результаты и обсуждение}

При анализе данных по перинатальной смертности установлено снижение показателя в 2,5 раза - с 14,3 до 5,7 (на 1000 родившихся; рис. 1). Уровень перинатальной смертности в г. Омске был выше, чем в целом по стране за анализируемый период, среднемноголетний показатель составил 10,1 и 9,7 (на 1000) соответственно, однако темп снижения этого пока-

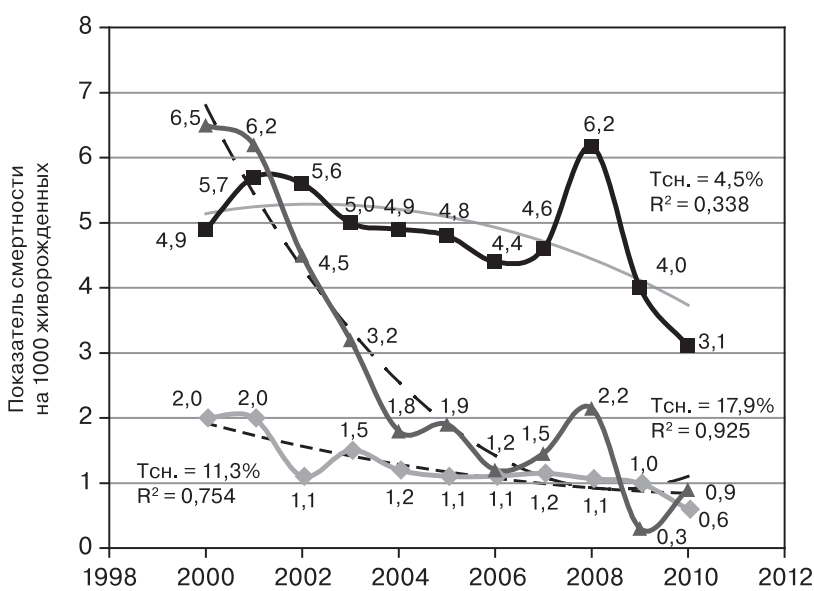

\footnotetext{
$\longrightarrow$ Интранатальная смертность в г. Омске

$\longrightarrow$ Антенатальная смертность в г. Омске

—_ Ранняя неонатальная смертность в г. Омске

- - - - Полиномиальный (Интранатальная смертность в г. Омске)

—— Полиномиальный (Антенатальная смертность в г. Омске)

- - Полиномиальный (Ранняя неонатальная смертность в г. Омске)
}

Рисунок 2. Динамика интранатальной, антенатальной и ранней неонатальной смертности (на 1000 живорожденных) в г. Омске за 2000-2010 гr. зателя в г. Омске превосходит общероссийский в 1,7 раза (8,8 против $5,3 \%$ соответственно). Анализ динамики перинатальной смертности в г. Омске по структурным компонентам выявил, что за 2000-2010 гг. в наибольшей степени снизился показатель ранней неонатальной смертности: с 6,5 до 0,9 на 1000 детей, родившихся живыми и мертвыми (Тсн. = 17,9\%; рис. 2).

Анализ заболеваемости внутриутробными инфекциями новорожденных различного срока гестации показал, что среднемноголетний показатель синдрома задержки развития плода у доношенных новорожденных составил 59,9 (Тпр. =9,5\%), у недоношенных - 84,1 (Тпр. = $16,5 \%)$. Показатель врожденных аномалий развития на 1000 родившихся также оказался выше у доношенных $(56,5$; Тпр. $=5,1 \%)$, чем у недоношенных $(27,4$; Тпр. $=3,9 \%)$, и быстрее нарастал в динамике за исследуемый период. Вместе с тем, заболеваемость внутриутробными инфекциями была достоверно выше у недоношенных, где среднемноголетний показатель составил 184,4 (против 168,1 у доношенных), и практически не менялся за анализируемый период (Тпр. $=0,03 \%)$. Обращает на себя внимание тот факт, что на фоне снижения перинатальной смертности и ее составляющих заболеваемость новорожденных внутриутробными инфекциями в г. Омске продолжает расти (рис. 3 и 4), при этом особо следует выделить группу доношенных новорожденных, где отмечается значительный прирост показателя за счет ВУИ (Тпр. = $9,0 \%)$.

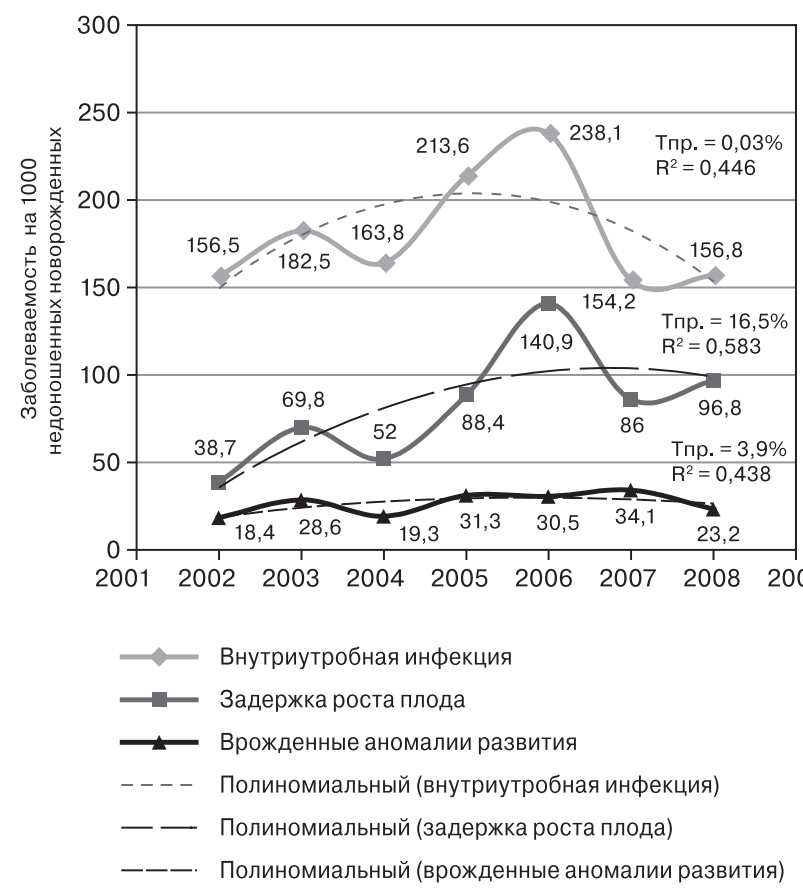

Рисунок 3. Динамика показателей заболеваемости недоношенных новорожденных (на 1000) в г. Омске за 2002-2008 гг. 


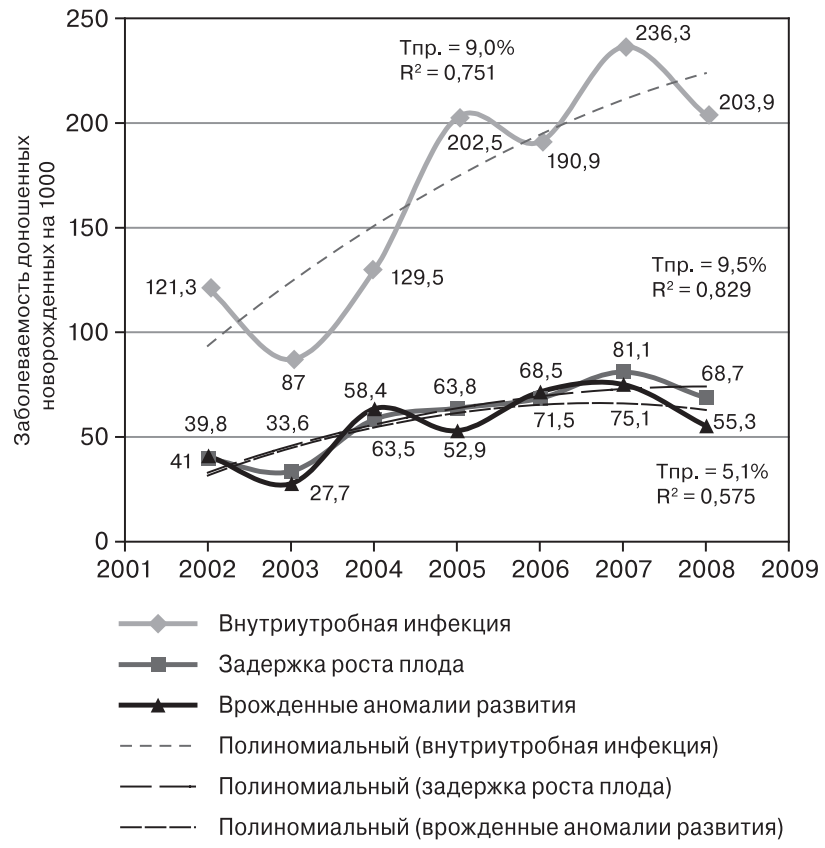

Рисунок 4. Динамика показателей заболеваемости доношенных новорожденных (на 1000) в г. Омске за 2002-2008 гг.

При обследовании 187 новорожденных методом ПЦР наличие моноинфекции установлено в 24\% случаев, а микст-инфекции - в $7 \%$ случаев. При этом первое ранговое место занимали герпесвирусы, среди которых следует отметить роль НHV-6 (он детектирован у $25 \%$ детей), ДНК HSV1,2 (обнаружена в 12,5\% случаев) и CMV (в 27,5\%; рис. 5). В состав ассоциаций инфекций вошли EBV, L. monocytogenes, CMV и RS-virus.

При анализе результатов обследования новорожденных с ВУИ, где ведущими патогенами оказались герпесвирусы (HSV1,2, HHV-6, CMV, EBV), и детей из группы сравнения установлены достоверные различия по содержанию: $\mathrm{CD}^{+}$,

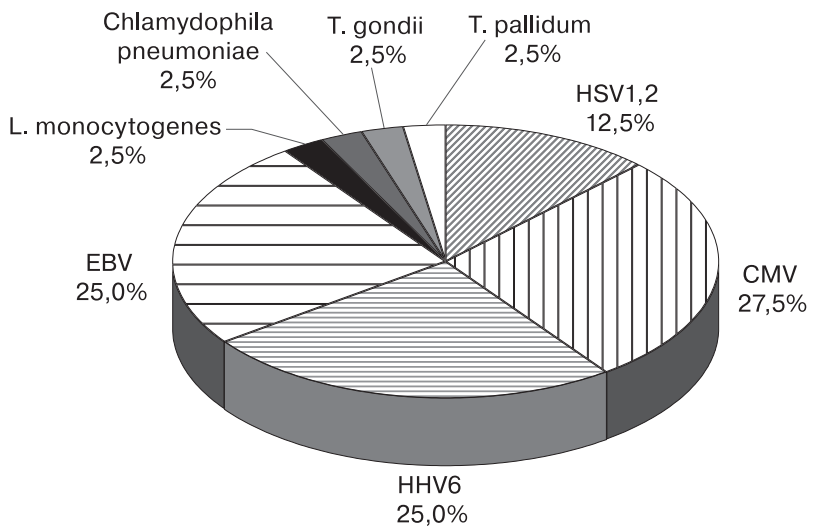

Рисунок 5. Структура внутриутробных инфекций при ПЦР диагностике, $\mathrm{n}=187$

$\mathrm{CD}^{+} / 4^{+}, \mathrm{CD}^{+} / 8^{+}, \quad \mathrm{CD}^{+} / 16^{+} / 56^{+}, \mathrm{CD}^{+} / \mathrm{HLA}^{-}$ $\mathrm{DR}^{+}$, IRI, $\mathrm{CD}^{+} / 50^{+}, \mathrm{CD}^{+} 4^{+} / \mathrm{HLA}^{-\mathrm{DR}^{+}}$(табл. 1). Несмотря на общий сниженный уровень Ти В-лимфоцитов у детей с ВУИ было повышенно содержание клеток эффекторного звена иммунной системы, которые сигнализируют об активации иммунитета преимущественно по Тh1 пути - это Т-цитотоксические лимфоциты, активированные лимфоциты $\left(\mathrm{CD}^{+} /\right.$ HLA-DR $\left.^{+}\right)$, активированные моноциты $\left(\mathrm{CD}^{+}{ }^{+} /\right.$ $\mathrm{HLA}-\mathrm{DR}^{+}$), а также $\mathrm{CD}^{+} / 25^{+}$, несущие рецептор K IL-2. Весьма интересным на наш взгляд является тот факт, что уровень моноцитов, экспрессирующих HLA-DR антиген, у детей с ВУИ, из которых 64\% были недоношенными, равнялся $60,4 \%[31,2 ; 70,6]$ и превысил такой же показатель у детей из группы сравнения в 4,8 раза $(\mathrm{p}<$ $0,05)$. Мы полагаем, что при реализации инфекции моноциты крови уже в периоде внутриутробного развития начинают экспрессировать на своей поверхности антиген HLA-DR раньше и в большей плотности, чем у детей с более зре-

\section{ТАБЛИЦА 1. РЕЗУЛЬТАТЫ ИММУНОФЕНОТИПИРОВАНИЯ ЛИМФОЦИТОВ ПЕРИФЕРИЧЕСКОЙ КРОВИ НОВОРОЖДЕННЫХ С ВУИ И ДЕТЕЙ С ПЕРИНАТАЛЬНЫМ ПОРАЖЕНИЕМ ЦНС ГИПОКСИЧЕСКОГО ГЕНЕЗА, \% (ГРУППЫ 1 И 2)}

\begin{tabular}{|c|c|c|}
\hline Фенотипические маркеры & Группа 1 [n = 162; Me (Q1;Q2)] & Группа 2 [n = 25; Me (Q1;Q2)] \\
\hline $\mathrm{CD}^{+} / 19^{-}$ & $59,6(52,1 ; 69,7)$ & $71,7(65,5 ; 73,5)^{\star}$ \\
\hline $\mathrm{CD}^{+} / 4^{+}$ & $30,2(20,6 ; 48,1)$ & $53(47,7 ; 55,4)^{\star}$ \\
\hline $\mathrm{CD}^{+} / 8^{+}$ & $20,6(15,4 ; 26,2)$ & $15,8(12,2 ; 18,1)^{\star}$ \\
\hline $\mathrm{CD}^{-} / 19^{+}$ & $6,8(4,3 ; 11,4)$ & $10,1(6,9 ; 14)$ \\
\hline $\mathrm{CD}^{-} / 16^{+} / 56^{+}$ & $8,4(5,5 ; 13,6)$ & $11,1(8,7 ; 12,7)$ \\
\hline $\mathrm{CD}^{+} / 25^{+}$ & $2,9(1,2 ; 4,9)$ & $1,7(1,4 ; 2,9)$ \\
\hline $\mathrm{CD}^{+} / \mathrm{HLA}^{-\mathrm{DR}^{+}}$ & $0,4(0,2 ; 1,7)$ & $0,1(0,0 ; 0,1)^{\star}$ \\
\hline $\mid \mathrm{RI}$ & $1,2(0,9 ; 2,1)$ & $3,5(2,9 ; 4,4)^{\star}$ \\
\hline $\mathrm{CD}^{+} / 95^{+}$ & $1,3(0,4 ; 2,3)$ & $1,4(0,6 ; 3,3)$ \\
\hline $\mathrm{CD}^{+} / 50^{+}$ & $60(49,8 ; 70,8)$ & $71,7(62,7 ; 74,6)^{\star}$ \\
\hline $\mathrm{CD} 14^{+} / \mathrm{HLA}-\mathrm{DR}^{+}$ & $60,4(31,2 ; 70,6)$ & $12,7(7,7 ; 20,0)^{\star}$ \\
\hline $\mathrm{CD}^{+} / 19^{+}$ & $2,9(1,2 ; 4,5)$ & $2,2(1,1 ; 3,1)$ \\
\hline
\end{tabular}

Примечание. Ме - медиана, Q1 - нижний квартиль, Q2 - верхний квартиль; * - наличие статистически значимых различий между сравниваемыми группами $(p<0,05)$, критерий Манна-Уитни (U). 
лой к моменту рождения иммунной системой, компенсируя тем самым дефицит активированных клеток моноцитарно-макрофагального звена, направленных на борьбу с инфекцией.

У детей из 1 группы выявлена значимая положительная корреляционная зависимость между уровнем моноцитов и уровнем IL-8 (r = 0,61), которые и являются основными продуцентами данного хемоаттрактанта, играющего важную роль в нормальной и патологической физиологии человека [9]. Таковой связи не наблюдалось у детей из группы сравнения, где была установлена отрицательная зависимость моноцитов с ангиогенным ростовым фактором (VEGF) и хемокином MIP-1 $\beta$ ( $\mathrm{r}=-0,57$ и $\mathrm{r}=$ $-0,59$ соответственно).

Уровень показателей цитокиновой системы в целом у детей с ВУИ имел тенденцию к росту по всем из 27 определенных параметров

\section{ТАБЛИЦА 2. УРОВЕНЬ ЦИТОКИНОВ В ПЛАЗМЕ КРОВИ НОВОРОЖДЕННЫХ С ВУИ И ДЕТЕЙ С ПЕРИНАТАЛЬНЫМ ПОРАЖЕНИЕМ ЦНС ГИПОКСИЧЕСКОГО ГЕНЕЗА, ПГ/МЛ (ГРУППЫ 1 И 2)}

\begin{tabular}{|c|c|c|}
\hline & $\begin{array}{c}\text { Группа } 1[n=162 ; \\
\operatorname{Me}(Q 1 ; Q 2)]\end{array}$ & $\begin{array}{c}\text { Группа } 2[n=25 ; \\
\operatorname{Me}(Q 1 ; Q 2)]\end{array}$ \\
\hline IL-2 & $4,7(2,4 ; 7,2)$ & $2,5(1,6 ; 3,7)$ \\
\hline IL-4 & $1,4(0,9 ; 1,9)$ & $1,3(1,2 ; 1,5)$ \\
\hline IL-5 & $1,1(0,5 ; 2,7)$ & $0,9(0,5 ; 1,4)$ \\
\hline IL-7 & $7,3(3,4 ; 12,9)$ & $5,1(3,4 ; 8,4)$ \\
\hline IL-9 & $2,2(0,0 ; 9,6)$ & $1,0(0,0 ; 6,0)$ \\
\hline IL-10 & $1,1(0,0 ; 2,6)$ & $0,3(0,1 ; 1,6)$ \\
\hline IL-13 & $0,1(0,0 ; 1,9)$ & $0,0(0,0 ; 0,6)$ \\
\hline IL-15 & $5,9(4,7 ; 7,0)$, & $5,6(4,5 ; 7,0)$ \\
\hline $\mathrm{IFN} \gamma$ & $19,5(14,4 ; 29,1)$ & $19,1(16,5 ; 22,8)$ \\
\hline IL-8 & $27,8(7,1 ; 79,7)$ & $4,4(2,9 ; 4,9)^{\star}$ \\
\hline IP-10 & $196(103 ; 442)$ & $189(108 ; 406)$ \\
\hline MCP-1 & $0,4(0,2 ; 0,5)$ & $0,4(0,2 ; 0,5)$ \\
\hline MIP-1 $\alpha$ & $3,4(2,4 ; 4,5)$ & $3,1(2,7 ; 3,8)$ \\
\hline MIP-1 $\beta$ & $62,6(40,4 ; 96,8)$ & $49,1(35,6 ; 86)$ \\
\hline RANTES & $148(143 ; 158)$ & $148(145 ; 152)$ \\
\hline Eotaxin & $28,4(19,3 ; 45)$ & $24,7(16,8 ; 44,5)$ \\
\hline G-CSF & $14,9(11,5 ; 19,4)$ & $12,5(10,9 ; 16,2)$ \\
\hline GM-CSF & $9,6(5,1 ; 14,6)$ & $8,1(5,0 ; 10,9)$ \\
\hline IL-1 $1 \beta$ & $1,6(0,0 ; 2,3)$ & $0,6(0,3 ; 0,9)$ \\
\hline IL-1RA & $269(122 ; 347)$ & $174(93,2 ; 190)$ \\
\hline FGF basic & $9,9(1,1 ; 16,3)$ & $6,9(3,1 ; 13,5)$ \\
\hline TNF $\alpha$ & $8,9(4,9 ; 14,4)$ & $7,9(6,3 ; 8,7)$ \\
\hline IL-6 & $5,2(2,8 ; 11,2)$ & $3,2(2,5 ; 4,3)$ \\
\hline IL-12 & $2,2(0,7 ; 4,8)$ & $1,9(0,5 ; 3,2)$ \\
\hline IL-17 & $15,4(4,1 ; 26,1)$ & $9,2(5,1 ; 13,2)$ \\
\hline PDGF-BB & $3220(1670 ; 3530)$ & $2990(1200 ; 3610)$ \\
\hline VEGF & $80,7(13,9 ; 139)$ & $34,2(18 ; 103)$ \\
\hline
\end{tabular}

Примечание. Ме - медиана, Q1 - нижний квартиль, Q2 - верхний квартиль; * - наличие статистически значимых различий между сравниваемыми группами $(p<0,05)$, критерий Манна-Уитни (U). (табл. 2), более выраженную у недоношенных по содержанию хемокинов (IL-8, IP-10, MIP-1 $\alpha$, MIP-1 $\beta$, Eotaxin). Известно, что IL-8 может оказывать свое влияние помимо нейтрофилов и на другие клетки. Особенно важным наблюдением является то, что он, как и все хемокины, играет важную роль в нормальном пренатальном развитии организма и способен модулировать продукцию провоспалительных цитокинов мононуклеарными клетками [9]. Его концентрация в крови детей с ВУИ была в 6,3 раза выше, чем у новорожденных из группы сравнения $(\mathrm{p}<0,05)$.

Таким образом, приведенные факты указывают на важность эпидемиологического мониторинга инфекционной перинатальной патологии на конкретной территории. В г. Омске отмечается высокий уровень антенатальной смертности и рост заболеваемости внутриутробными инфекциями доношенных новорожденных. По данным этиологической расшифровки в формирование перинатальной патологии значительный вклад вносят вирусы семейства Herpesviridae с повышением патогенетической значимости EBV и HHV-6, а также вирусно-бактериальные ассоциации.

У детей с инфекцией отмечается напряженность иммунитета уже в периоде внутриутробного развития, причем иммунный ответ формируется в основном за счет врожденного иммунитета - цитокинов, а также запуска факторов адаптивного иммунитета - Т-лимфоцитов, с поляризацией ответа по Тh1-пути. Установлено достоверное превышение уровня цитотоксических Т-лимфоцитов и экспрессии антигена HLA-DR на моноцитах у детей с ВУИ в сравнении с детьми с гипоксией ЦНС. Реализация ВУИ сопровождается повышением содержания хемокинов в крови новорожденных (в отличие от детей с гипоксическим поражением ЦНС). Достоверно установлено превышение уровня IL-8, который может использоваться как маркер реализации внутриутробной инфекции.

\section{Список литературы}

1. Бубнова Н.И., Тютюнник В.Л., Михайлова О.И. Репродуктивные потери при декомпенсированной плацентарной недостаточности, вызванной инфекцией // Акушерство и гинекология. 2010. - № 4. - С. 55-58.

2. Буданов П.В., Стрижаков А.Н. Этиология, патогенез, диагностика и лечение внутриутробной инфекции // Вопросы гинекологии, акушерства и перинатологии. - 2010. - Т. 9, № 3. - С. 61-71.

3. Володин Н.Н. Актуальные проблемы неонатологии. - М.: ГЭОТАР-МЕД, 2004. - 448 с.

4. Гервазиева В.Б., Самойликов П.В. Взаимодействие вирусов семейства Herpesviridae с иммунной системой человека // Аллергология и иммунология. - 2010. - Т. 11, № 1. - С. 31-41. 
5. Гончаров Д.Б. Значение персистенции Toxoplasma gondii в клинической патологии человека // Журнал микробиологии, эпидемиологии и иммунобиологии. - 2006. - № 4. - С. 92-97.

6. Долгих Т.И. Токсоплазмоз: современная стратегия лабораторной диагностики // Инфекция и иммунитет. - 2011. - Т. 1, № 1. - С. 43-50.

7. Долгих Т.И., Мироненко М.М., Шелев М.В. Этиологическая характеристика инфекционных заболеваний перинатального периода в Омской области // Эпидемиология и инфекционные болезни. - 2011. - № 2. - С. 8-12.

8. Карапетян Т.Э., Антонов А.Г. Значение оппортунистических инфекций влагалища в развитии внутриутробной инфекции плода и новорожденного (ретроспективное исследование) // Акушерство и гинекология - 2010. - № 4. - С. 59-63.

9. Кетлинский С.А., Симбирцев А.С. Цитокины. СПб.: Издательство Фолиант, 2008. - 552 с.

10. Кулаков В.И., Сухих Г.Т., Кан Н.Е., Верясов В.Н., Орджоникидзе Н.В. Содержание цитокинов в амниотической жидкости, пуповинной крови и сыворотке крови женщин с внутриутробной инфекцией // Акушерство и гинекология. 2005. - № 5. - C. 14-17.

11. Кравченко Л.В. Состояние иммунной системы у детей первых месяцев жизни с герпесвирусной инфекцией // Педиатрия. - 2008. - № 1. P. 52-58.

12. Макаров О.В., Алешкин В.А., Савченко Т.Н. Инфекции в акушерстве и гинекологии. МЕДпресс-информ, 2007. - 464 с.

13. Никонов А.П., Асцатурова О.Р. Цитомегаловирусная инфекция // Педиатрия. -2009 . - № 1. C. 7-10.

14. Пастман Н.М., Черных Е.Р., Хонина Н.А., Дударева А.В., Тихонова М.А., Останин А.А., Кустов С.M. Иммунный статус женщин группы высокого риска по преждевременному прерыванию беременности // Вопросы гинекологии, акушерства и перинатологии. - 2010. - Т. 9, № 4. - С. 28-32.

15. Радзинский В.Е., Димитрова В.И., Майскова И.Ю. Неразвивающаяся беременность. - М.: ГЭОТАР-Медиа, 2009. - 2000 с.

16. Савичева А.М., Шипицына Е.В. Перинатальные инфекции: проблемы и пути их решения // Акушерство и гинекология. - 2009. - № 3. C. $33-38$.

17. Степаненко С.Ф. Снижение риска инфекционновоспалительных заболеваний в системе «матьноворожденный» // Сибирский мед. журн. 2007. - T. 22. - № 3. - C. 102-115.

18. Чистякова Г.Н., Газиева И.А., Ремизова И.И., Черданцева Г.А., Черешнев В.А. Оценка цитокинового профиля при физиологической и патологически протекающей беременности // Цитокины и воспаление. - 2007. - Т. 6, № 1. - С. 3-8.

19. Шестакова И.В., Ющук Н.Д. Эпштейна-Баррвирусная инфекция у взрослых: вопросы патогенеза, клиники и диагностики // Лечащий врач. 2010. — № 10. - С. 40-44.

20. Bessières M.H., Berrebi A., Cassaing S., Fillaux J., Cambus J.P., Berry A., Assouline C., Ayoubi J.M., Magnaval J.F. Diagnosis of congenital toxoplasmosis: prenatal and neonatal evaluation of methods used in Toulouse University Hospital and incidence of congenital toxoplasmosis // Mem. Inst. Oswaldo Cruz. 2009. - Vol. 104, N 2. - P. 389-392.

21. Douvoyiannis M., Litman N., Goldman D.L. Neurologic manifestations associated with parvovirus B19 infection // Clin. Infect. Dis. - 2009. - Vol. 48, N 12. - P. 1713-1723.

22. Eskild A., Bruu A.L., Stray-Pedersen B., Jenum P. Epstein-Barr virus infection during pregnancy and the risk of adverse pregnancy outcome // B.J.O.G. 2005. - Vol. 112, N 12. - P. 1620-1624.

23. Murth V., Kennea N.L. Antenatal infection inflammation and fetal tissue injury // Clin. Obstet. Gynaecol. - 2007. - Vol. 21. N 3. - P. 479-489. 